\title{
Analysis the Role of Media Perspectives on General Communication and Islamic Communication
}

\author{
Junita Irawati \\ Sekolah Tinggi Agama Islam Negeri Mandailing Natal, Indonesia \\ junitairawati15@gmail.com
}

\begin{abstract}
Research on general communication and Islamic perspective communication Public communication is an issue that is often discussed in human life today, because with communication can move the human condition. With communication, even a community can find out information. Likewise Islamic communication themes are found in the Qur'an. The terminology of communication in al-Qur'an includes, among others: Al-Ittiāşal, al-I'lam, al-Tabshìr, al-Da'wah, al-Bayan, al-Naba, al-Khabar, alQaul. This sentence is understood as the basic word of communication which is the basis for making that communication exist in the Qur'an. This research method uses a library research approach and content study. Using intrapersonal communication theory.
\end{abstract}

Keywords

services, administration; regional office ministry of religion

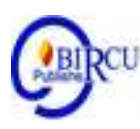

\section{Introduction}

Communication is the process of delivering messages by someone to other people to tell, change attitudes, opinions or behavior either directly orally or indirectly through the media. In this communication requires a reciprocal relationship between the delivery of messages and recipients namely communicators and communicants. (Hasbullah, 2018)

Communication can maintain and move lives. He is also a mobilizer and tool to describe the activities of society and civilization, he can turn instinct into inspiration through various processes and systems for asking, ordering and supervising, he can create a place to store ideas together, strengthen feelings of togetherness by exchanging news and changing the mind becomes an act that describes every emotion and need from the effort to preserve the simplest life to the very scientific human endeavor or the attempt for destruction.

Communication is a combination of science, organization and power in the form of a common thread that starts from memory to the noblest appreciation in an effort to lead a better life. Even communication and explanation of information can change the strength of a nation to be negative and positive. So that gave birth to a new paradigm. A communication with the dissemination of news, information and delivery to the public and the public often get a variety of different responses and responses if the delivery does not have a foothold of principles and codes of ethics that are accurate and true, even some that cause slander and disaster.

Almost a noble family in ruins, if Allah did not send verses that show the falsity of the news. The verse is a warning to Muslims and Muslims not to easily spread false / vile news or information and does not contain the truth.

The Word of God Almighty: Meaning: Allah warns you (do not) re-do such things forever, if you are a believer. Allah explains His verses to you. and Allah knows the Wise. Verily those who want to make (the news of) such abominable deeds spread among those 
who believe, for those who suffer the doom in the world and the hereafter. and Allah knows, while, you do not Know. (Q. An-Nŭr: 17-18).

Presumably, these are some of the verses that came down to provide principles and ethics of communication, especially with regard to the spread of news and information in the midst of society. Shaykh Makarim Shirazi explained the painful punishment in the world as the necessity of severe legal sanctions with the laws in the world. So, spreading false news must be considered a criminal act.

On this basis the author wishes to examine how ideally the principles of communication in the Koran should be used as a foothold in conveying, whether information, news, or messages especially those concerned with religious matters. Because al-Qur'an must be believed and felt as: Instructions (guidance for humans in general, and those who fear in particular). Furqān (distinguishing between right and vanity, between real and fictional, between absolute and relative) Rahmat (spreader of love) Syifâ (antidote, especially for restless and restless hearts), Mau'iżah (advice, advice), advice) Zikr li al-'Â amâmîn (warning to all nature) Tibyânan li kulli syai '(details for something) and so forth. All of these give an indication that the Qur'an is a holy book that has many dimensions and offers very broad insight.

In this research, we will see how the principles or rules of communication found in the Qur'an, both directly and indirectly. This does not mean comparing or even equalizing both, because in essence it must be all humans can socialize the content of the Qur'an as a holy book. However, the sharp concern in this case is how the concepts presented by God and how the reality that occurs and applies in the West. Especially the non-Islamic world which incidentally does not use the basis of his life with the Qur'an.

\section{Research Method}

This research is in the form of a pure library (library), in the sense that all data sources come from written materials related to the topics discussed. Because this study deals with alQur'an / revelation directly, then the first and main source is al-Qur'an. The fluidity of secondary data sources, namely books, including magazines related to this paper that have been considered scientific and have been published. The theory used is Intrapersonal Communication, namely: Information processing. This intrapersonal theory has four systems, namely: Memory Thinking, Perception Sensation. These four systems describe how people receive information, process it, store it and produce it again. The fourth series of these systems can be concluded that the explanation is: Sensation is the process of capturing stimuli. Perception is the process of giving meaning to sensations so that humans gain new knowledge. Giving is storing information and calling back. Thinking is processing and manipulating information to meet needs or responses.

\section{Discussion}

Technological and industrial revolution that resulted in changes in the exchange of human life and the nature of the press itself. There are sharp criticisms directed at per situ itself because the mass media is growing both in quality and quantity. There are professional developments where journalism has amazed human thought and education. It is clear that the target-target of notification and providing news is something realistic in the lives of those who consider the world of journalism to make a significant contribution. In addition to the above, including the principle of communication found in public communication and in the 
West is freedom. Westerners regard "freedom" as a human right that cannot be contested, even the government must not interfere. The struggle for freedom of expression is a longstanding struggle by groups of people and individuals for their political environment.

It can be seen that public communication or that is used in the western world views that communication and information are commodity goods that can be traded. In every communication activity the greatest benefit is obtained by the main communicator who masters information. Everyone is free to express opinions both verbally and writing without any obstacles and consideration to the values held by other parties. Whereas according to the perspective of Islamic communication is, the greatest advantage in delivering information lies with the communicant (the target of information) not the communicator. Submission of information is essentially aimed at realizing the happiness and well-being of the individual or society that is the target of communication. Besides that, freedom of communication must be coupled with a sense of responsibility and be accompanied by values shared by the nation and state society.

This liberal system developed in the seventeenth and eighteenth centuries as a result of the emergence of the Industrial Revolution and major changes in the thoughts of society in the west at that time, better known as the century of division. According to this theory humans basically have the natural rights to teach the truth and develop potential when given the clemency of opinion. This is not possible if there is government control. This theory developed in the West which adheres to the philosophy of "Laiser Fair Laiser Passer". The basic principle of Liberalism can be seen from the view of this school regarding the nature of man, the relationship between man and man, with society and the State, as well as the nature of truth and knowledge. According to the ideology of liberalism, humans are essentially born as free creatures that are controlled by reason and reason, the happiness and welfare of individuals is the goal of society, nation and state. Thus the most important thing that stands out in this system and principle is freedom of expression, freedom of speech, freedom of conduct, as long as it does not interfere with the interests of the State and nation.

The issue of freedom (in this case including the press) should not only be seen as an aspect of freedom of expression, but also as a need to protect institutions which are important functions in protecting the economic, political image and including towards the changes desired by society. Therefore press freedom in the West is a history of suppressing unpopular ideas. Thus the State as the highest authority over political, economic and social truth has more to do than in its own name to maintain its existence.

The freedom that is carried in Western countries in disseminating information, ideas and so on depends very much on the needs, both collectively and individually. The benefits achieved from such freedom do not harm any party in general. It seems that this condition is a bias of democracy which is always touted. Freedom of human behavior is not prohibited as long as it is still within the limits of democracy.

In the context of increasing freedom in reporting, the delivery of communication, especially press freedom at the international level, especially in the West, has been raised since 1893 through various international conferences held by journalists. But the meeting did not produce anything significant. The meeting was nothing more than just issuing a resolution or pledge to fight for the press. Very few tangible results have been achieved. Whereas what they had been able to complete had been erased again by propaganda during the two world wars that arose later.

Ideally, the expected freedom of the press is: Prohibition of government intervention into the press in the form of concrete actions that can disrupt the smooth flow of information, and the principles of limiting press freedom must be applied through the court, that the court is authorized to carry out punishment. Freedom in conveying news and information, freedom 
of the press should not be detrimental to certain parties, even though freedom for the press is owned but still in its essence, namely truth.

In exercising freedom, especially the world of the press very much helps the needs of the people and society including in developing countries. The press really should be able to double the change, accelerate change, become a democratic institution, a reintegration institution and a provider of institutions giving norms and new cultures. Fulfilling the function of freedom in the West in the context of freedom of the press will certainly help people overcome the symptoms of social change. But there is still the fact that freedom is still controlled or intercepted by the authorities, especially countries that are still led by the King.

In the perspective of Islamic communication based on the Qur'an and al-Hadith, it seems to be very tolerant in limiting these principles, as long as they remain within Islamic criteria, and can be detailed as follows:

\section{Al-Ihtiyat wa al-Tsiqah ( ألأحطياط و الثيــقة )}

This term is widely used in receiving and delivering religious news, especially Hadith. People who do not have and do not have the nature of prudence and the accuracy of the impact and influence of the news delivered without accurate, news from the wicked must be clarified (tabāyun).

The principle of Islamic communication must be based on al-ihthiyat and al-tsiqah, namely: caution and accuracy. Communicators are highly required to have the nature of trustworthiness and honesty not only in accessing news, but in all respects, do not have a dual and hypocritical nature. Also he must really maintain the qualities that can eliminate selfesteem. When he is dealing with problems he does not engage in data manipulation. He not only relies on accurate data and data, but more deeply his personality is scrutinized. His words and actions must be in line. This is where the difference with the principles adopted in the Western world. The most important thing is accurate data and news. His personality and role models are not in the spotlight.

The basic foundation of Islamic principles is that it can be seen from the stringent requirements set by Islamic scientists in receiving news, information especially relating to the teachings of Islam, including the hadith of the Prophet Muhammad SAW, transparently stipulating the news he was carrying if he was not careful, he would definitely reject it even though he brought data rational. Because the main criteria that are in the spotlight are the traits attached to one's personality, namely caution. Because the problem of a clean personality is the main assessment and greatly determines the existence of what he conveyed. Thus, if it is related to the world of information, especially the world of journalism, it is ideal that the code of ethics in selecting hadiths can be coupled with the requirements of a communicator in accessing news. Because thus it will be more awake from the dangers of the intended manipulation of the news.

$$
\text { An-Naaqid (ألنــاقد) }
$$

A communicator said that what is right is right and what is wrong is wrong. This is an obligation for every individual. One of the main principles and ethics of communication is to make corrections and criticisms that can build up on things that are not according to what they should, both in terms of applicable laws and according to the ethics and norms that live in the community. The press should ideally function as the keeper of the truth in the middle of the reader. All deviations must not be allowed. By way of the press doing criticism and 
correction so that irregularities do not take place again. Allowing distortion in the middle of society is tantamount to letting the community suffer.

In the Koran the task of conveying the truth is an order that must be carried out by each individual through his own work or organization. Al-Qur'an itself in the form of presentation also illustrates the commands, prohibitions and also statements and information of previous people in various stories. Not only are the stories good and successful, but there are also stories that fail in carrying out its mission. Both sides of the story are intended so that humans can learn, so that bad events are not repeated and successful events can be repeated and examined after being modeled again by living people in the next age.

According to the verses of the Qur'an, a believer is asked to carry out an obligation in the form of work inviting others to do good, telling people to do good and forbidding people to avoid evil. As found in the Qur'an Al -li Imran: 104.

Meaning: Let there be among you a group of people who call for virtue, order to the ma'ruf and prevent from evil; they are the lucky ones.

Amar ma'ruf nahi munkar's work is done with only one goal, which is to become a successful person or win. If observed from this verse it is true that not every individual believer is required to carry out this command, because of his differences in ability. However, essentially every individual has an obligation to preach in accordance with their abilities. The ones who are told to appear professional are just a part of many believers.

Word: Ummah in this verse is interpreted by Mustafaf Al-Maragghi with: A congregation consisting of individuals who have attachments to one another like members of the human body. The Ummah is a special group (professional) who is able to carry out the invitation (al-Da'wah), able to order and be able to prevent. Everyone has desires and works. To realize the improvement of the Ummah, even in the early period of Islamic development, all people participated in carrying out corrections and criticisms of the existence of irregularities and abuse of office. Penguasapun must be open-hearted to be corrected by the people. Once when Umar bin Khattab preached "If you see any deviation in me, correct you" then a goat herder stood up and immediately asked and answered "If we see you have irregularities we will straighten you with our swords" this means the people have authority to improve the situation and be responsible for carrying out the da'wah duties.

People who are required to preach are people who have certain requirements. There are at least four conditions that are possessed to become preachers who excel, namely: First: Having knowledge about the Qur'an and Sunnah and the history of the Companions and Khulafa al-Rashidin, Second: Knowing the situation and condition of the audience, abik facet adapt customs, character and morals as well as matters that are sociological, Third: Knowing the language of the people, Fourth: knowing the ins and outs of religious streams and differences of opinion of the people. The actors of communication, especially those who are involved in the world of journalists, belong to the people who are said to have a role in making changes to the good. Because the reporters have the same mission with the da'wah as found in al-Da'wah.

In this case according to the opinion of the writer, here there are differences in the principle of public or Western communication, where they consider making corrections, criticisms and changes only limited to attitudes and as the responsibility of personnel and or individuals. Whereas in Islam, it is part of the fundamental religious teachings and collective obligations. Criticizing leaders, officials, both formally and informally is a competent obligation. In this case, the mass media, for example, who criticize anyone, must have a mission and goals of the interests of the people together, not one-sided interests that are only used by certain people. As an indicator of the behavior above is going to give birth to humans, society or the best group (khaira ummah) for other people (believers), of course the 
khaira al-ummah group can be realized if they are able to carry out their mission as telling others to do good and able take precautions against people who commit evil. This is found in the Qur'an in the Letter of Imran: 110.

Meaning: You are the best people who are born for human beings, commanded those who are sorry, and prevent those who are evil, and have faith in Allah. if the experts of the Book of faith, surely it is better for them, among them there are believers, and most of them are people who are wicked.

In essence, as long as the faithful do not carry out these tasks, so long as they are also considered as good people. So the measure of kindness towards people and a person is if he has a concern to improve people for the better. In the Qur'an, there are really many commands to do good in various matters of life and worship and verses in the form of a prohibition against bad deeds. All of this is a picture of al-Qur'an's concern as a source of Islamic teachings to improve the condition of society in order to achieve a better and more perfect quality of life, both the world and the hereafter.

The obligation to uphold the truth, correction in society is a call to someone without exception. The Hadith of the Prophet Muhammad stressed:

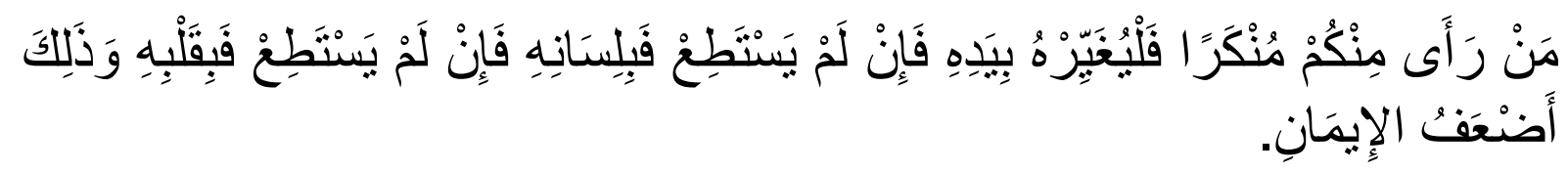

Meaning: If any of you see evil, he must change it with his hands. If he cannot, change it with his tongue, if he still cannot change it with his heart, and that is the weakness of faith. (HR. Muslim)

Changing confusion with the tongue in the above hadith can be understood as the authority to express opinions verbally and in writing, so that the possibility does not occur. The definition of "Fal yughoyyirhu" can be understood to change the situation, from small events which are still formed by symptoms to become no bigger, or when disasters occur to change so that disasters take place no longer. The above hadith is firm enough to provide legality for someone in fighting for the truth. Tongues and pliers which are used as media in da'wah through communication channels are interpersonal or missal.

Forms of change and improvement through communication according to William L. Rivers is, among others, by presenting a complete and accurate picture of the world to the reader. Any behavior that conflicts with this goal is suspect. The attitude of courage to uphold the truth is the main mission of people who work at the press institution, especially its ethical foundation, it can be seen to what extent he has concern for the fate of the public and dares to reveal the truth in accordance with facts and reality. Constructive criticism and correction that is expected to be realized by the communicator especially the media can fortify a variety of organized and unorganized crime. And not just bring down certain parties.

Al Hikmah ( أل حــكـة )

Professional communicators are encouraged to have the character of Al-Hikmah in carrying out its mission. Both those who work as journalists, preachers, teachers, managers and leaders in very small matters. In reality. Hymns in receiving and spreading and conveying information, there are differences between Western and Islamic views. In my opinion, the point of difference here is that Westerners understand wisdom in logic and reality. Its size is a match on reality at the time and was accepted by many people. The 
wisdom displayed in conveying the information referred to here is the timeliness, conditions, place of who is desired, which in essence no one is harmed.

Whereas in the perspective of Islam al-hikmah can be viewed from several points of view. The meaning can be understood from the language approach, for example, law or philosophy. However, the main discussion in this paper is the wisdom in the Qur'an. The expression of wisdom in the Koran has several purposes that fit the context of the sentence. In addition, the expressions have their respective characters based on these terms. However, in general the character can be returned to the meaning of the person who has wisdom (alhikmah), so that he avoids actions that cause remorse.

Sentences of wisdom in the Qur'an are addressed to many Prophets and Apostles. But the wisdom referred to here implies As-Sunnah, knowledge of halal and haram, about secrets that are not known to the layman. With this advantage, a Prophet and Apostle are given the task to call on the path of Allah.

As can be understood that the wisdom originated from and sourced from the book of Allah and the sunnah of the Prophet and saw the positive impact on the actions of people who get and be granted wisdom. While those who are not awarded wisdom, those who always make damage and destruction of this people, because of the attitude that causes to his people.

Lafaz wisdom in al-Qur'ān is found 30 times in Surat al-Baqarah five times revealed in Medina, in Surah Ali Imran there are four times, revealed in Medina, Surah al-Nisā there are two verses, Surat al-An'ām there is one verse revealed in Makkah, Surah Yünus has one verse, in Surah Y $\bar{u}$ suf there is one verse that is included in the Makkiyah verse. In Surat an-Nahl one verse was revealed in Makkah, Surat al-Isra one verse, Maryam one verse, al-Anbiyā 'two verses, al-Syu'arä' one verse. al-Qashash one verse, al-Rūm one verse, al-Ahzab one verse, Shad one verse, al-zukhruf two verses, al-Dukhan one verse and Surat al-Jumu'ah have one verse. And the verses of wisdom more revealed in Makkah, which is thirty-five verses than in Medina which there are only five verses.

In interpreting the wisdoms of the mufassirin, they give different interpretations and thoughts. And they explain it as follows:

a. As the task of the Apostles

$\mathrm{O}$ our Lord, send to them an Apostle from their circle, who will recite to them your verses, and teach them the Book (al Qur'ān) and Al-Hikmah (As-Sunnah) and purify them. Verily, You are the Almighty, the Wise. (Surat al-Baqarah: 129)

According to Ibn Abbas, what is meant by "al-kitab" is al-Qur'an, while what is meant by "al-hikmah" is Sunnah. And he also said that wisdom is fiqh which contains the provisions of halal and haram and the advice of the Qur'an. Referred to as a judge for wise people, because it prevents from ignorance. Muhammad Abduh said: Wisdom can be interpreted as a book or al-Qur'an, wisdom also means sunnah in general. Wisdom also means the secrets and benefits of something. If the teachings of the Prophet about wisdom are interpreted as the Prophet's teachings about the fiqh of the Islamic religion, then the important meaning of the hymn is the attitude of Islam. The Prophet taught them the Koran, in addition to the secrets of the objectives of sharia with various charities to Muslims. So that it can be used as an example for them, both deeds and words.

b. Advice

Including the interpretation of scholars about the meaning of al-hikmah is advice. This can be seen from various verses of the Holy Qur'an. For example in the safe letter of Luqman in this letter Allah explained the wisdom in the form of his advice to his child. The wisdom that is found in this Letter of Luqman Allah gave him as secrets that may not be given to others, so that his advice to his children is very actual to be carried out by anyone. 
The strengths that Allah gives to Luqman are God's secrets with no known reason. His wisdom in conveying religious teachings made him put as a successful parent. The languages he uses are very polite and wise, touching the audience when listening to them. The emphasis that is done at the earliest stage is the emphasis on monotheism, then finally the stage of morality and social institutions of human society.

In particular, there are many characteristics of people who have wisdom, such as virtue, including: Reasonable, knowledgeable, intelligent, intelligent, having sharp inner vision, understanding, just, having noble character, honest, tawadhu ', not paying attention to other people's disgrace, short talk subdue lust and so forth. Himah is a source of power to initiate alternative problems from mistakes in thinking and doing. Can avoid things that will be misleading, both in terms of aqeedah, sharia, morals, personal issues and the wider community.

With the concept of wisdom, everything will facilitate the process of communication between humans, both directly and indirectly. The real wisdom is a gift from God that not everyone gets. Business and theory to get owned by someone is not necessarily he managed to get it, because wisdom is an absolute right of Allah. People who are given wisdom means he has been given a lot of glory and goodness. A reliable communicator supported by wisdom skills will facilitate him to make various approaches that are perfect in the middle of this life and will be more protected from mistakes, gaps as well as defamation. Thus, it can be concluded that to obtain it is actually a matter of closeness to God.

This is actually not a requirement for a journalist, journalist or as an orator. In fact, this is never mentioned as a character, even though here there are advantages to success. In the west the most priority is objectivity. If objectivity is achieved, then the level of success is considered to meet the standards. News that is always disseminated to the community in the past is news and information that is expected not to offend and does not harm certain parties transparently. Then whether the content of the news is from people who are close to the teachings of their religion, whether the contents of the news have accurate data and can be accounted for in a legal and moral manner.

\section{Conclusion}

Communication is actually an activity carried out by someone to convey a message to another person, so that the person does what is meant by the person delivering the message. The essence of communication lies in the similarity of intentions or changes in the behavior of objects or targets. For its socialization as a science found several theories. In the Koran found symbols, words that signal communication as a necessity for humans in their lives.

In the course of human life, communication has a long history and varied forms and patterns. In the days before the Apostle, it was still done simply, that is by way of direct confrontation, and further information was carried out in the form of correspondence, this was until the time of the Apostles, Friends and Tabi'in. This fact can be seen when the Apostles and the Shabat spread the wings of Islam by writing a letter first to the intended audience. It is recorded by historians that the Apostle in delivering his missionary communication through letters 105 times. And the media used as a means of communication are increasingly sophisticated in accordance with the times and conditions so is Islamic communication.

The terminology of communication in al-Qur'an includes, among others: Al-Ittiāşal, alI'lam, al-Tabshìr, al-Da'wah, al-Bayan, al-Naba, al-Khabar, al-Qaul. This sentence is understood as the basic word of communication which is the basis for making that communication exist in the Qur'an. The principles of communication found in al-Qur'ān are: 
Al-Shidq (honest in conveying), Second: al-Adil (not taking sides) to anyone, Third: reasonable and proper to say, does not make people restless, agitated and provoked. Fourth: Al-Tsiqah (accurate) does not cause bad and negative thinking. Fifth: Al-Hurriyyah (free and responsible). Appropriate in conveying any information and messages using: Qoulan sadida, Qoulan Karima, Qoulan Baligha, Qoulan Ma'rufa, Qoulan Maysura, Qoulan layyina. This expression has a sharp meaning laden with wisdom and philosophical understanding.

The principle of Islamic communication has a difference with the principle of general communication or that is used in the West / libaral namely; The principle of Islamic communication expects Fre and balance flow of information while general or Western communication gives birth to the concept of Fre flow of information. Thus the freedom that they understand is freedom without limits while Islam is more upholding justice and humane. Islam views information as social goods rather than mere commodities. So that it takes a balance and social responsibility of communication actors.

\section{References}

Al-Qur'an al-Karim and Terjemahnya. (1998). Riyadh, Arab Saudi, Kementerian Agama dan Wakaf , Dimensi-Dimensi Komunikasi. Bandung, Remaja Karya, 1986.

Al-Farmawi, Abdu al-Haiyi'. (1979). Al-Bidāyah Fi al-Tafsīr al-Maudū'̄̄. Kairo, Dār alHadis.

Al-Ghazali, Bahri. (1997). Dakwah Komunikatif, Membangun Kerangka Dasar Komunikasi Dakwah. Jakarta, Pedoman Ilmu Jaya.

Al-Gurabi, Mustafa. (1959). Ali. Tārikh al-Firāq al-Islamiyah. Kairo, Maţba'ah al-Sahīh.

Al-Jauzi, Ibnu Muhammad, Abdu al-Rahman, Jamaluddin, Abi al-Faraj. (1994). I'dād alMaisir Fī al-Ilmi al-Tafsīr. Beirut, Dar al-Ilmiyah.

Al-Jauziyah, al-Qayyum, Ibnu. Zād al-Ma'ād. Dār al-Ihyā al-Turās al-'Arabiyah, t.t.p.

Ardial. (1997). Teori Komunikasi dan Pratek Islam.

Cangara, Hafied. (2002). Pengantar Ilmu Komunikasi. Jakarta, Raja Grafindo Persada.

De Vito, A, Joseph. (1979). Communication : And Introduction to The Study of Communication. New York, Harper, Publising.

Ecol, M, John. (1996). Kamus Inggris Indonesia. Jakarta, Gramedia.

Effendy, Ucahjana, Onong. (1984). Ilmu Komunikasi, Teori dan Praktek. Bandung, Rosydakarya.

Hasbullah, et ala. (2018). Communication Pattern of Wilayatul Hisbah, Lhokseumawe Cityin Implementing Amar Makruf Nahi Mungkar. Budapest International Research and Critics Institute-Journal (BIRCI-Journal). P. 194-205 